\title{
Pelatihan Kejuruan Pengolahan Hasil Pertanian Balai Latihan Kerja Sorong
}

\author{
Evi Mufrihah Zain', Febry Jein Andjar ${ }^{2}$, Devi $^{3}$ \\ 1,2,3 Fakultas Ekonomi , Universitas Muhammadiyah Sorong, Indonesia \\ Email. zevimufrihah@gmail.com
}

\begin{abstract}
ABSTRAK
Penelitian ini bertujuan untuk mempelajari bagaimana cara memanfaatkan sumberdaya alam untuk dihasilkan menjadi bahan pangan, mengolah bahan mentah menjadi berbagai macam produk yang bermanfaat dan untuk meningkatkan dampak perekonomian masyarakat, Penelitian ini menggunakan beberapa metode pendekatan yaitu pelatihan dan penyuluhan yang dilakukan di Balai Latihan Kerja Sorong. Pada umumnya masyarakat selalu menginginkan sesuatu yang berbeda, tidak terkecuali dengan hal kuliner atau makanan. Hasil olahan labu kuning dapat di olah menjadi beberapa makanan yaitu cake labu kuning, kue lumpur labu kuning, puding labu kuning ,karena di kota sorong sendiri pengolahan labu kuning biasanya hanya sebagai sayuran. Kesimpulannya melalui kegiatan pelatihan pengolahan labu kuning dapat menciptakan berbagai makanan yang mempunyai banyak varian yang dapat dikonsumsi.
\end{abstract}

Kata Kunci : Pelatihan Kejuruan, Hasil pertanian, Balai Kerja Sorong

\section{Vocational Training on Agricultural Product Processing, Sorong Work Training Center, 2020}

\section{ABSTRACT}

This study aims to study how to use natural resources to produce food, process raw materials into various kinds of useful products and to increase the impact of the community's economy. This study uses several approaches, namely training and counseling conducted at the Sorong Job Training Center. In general, people always want something different, including culinary or food matters. The processed pumpkin can be processed into several foods, namely pumpkin cake, pumpkin mud cake, pumpkin pudding, because in the city of Sorong itself, pumpkin processing is usually only a vegetable. The conclusion is that through training activities pumpkin processing can create various foods that have many variants that can be consumed.

Keywords : Vocational Training, Agricultural Products, Sorong Work Center

\section{PENDAHULUAN}

Menghadapi era globalisasi dan persaingan bebas, balai lembaga kerja Sorong melakukan penelitian tentang pertanian untuk mendapat perhatian demi meningkatkan nilai tambah hasil pertanian dan menjadikan kota Sorong sebagai pusat perekonomian masyarakat yang meningkat.(NurAini, 2004). Pertanian adalah kegiatan pemanfaatan sumber daya hayati yang dilakukan manusia untuk menghasilkan bahan pangan, bahan baku industri, atau sumber energi, serta untuk mengelola lingkungan hidupnya. Kegiatan pemanfaatan sumber daya hayati yang termasuk dalam pertanian biasa dipahami orang sebagai budidaya tanaman atau bercocok tanam seperti prosedur makanan. Indonesia sebagai Negara dengan ketersediaan sumberdaya alam yang 
melimpah merupakan modal dalam pengembangan atau penganekaragaman pangan ke masyarakat. Namun kenyataan yang terlihat pada kondisi masyarakat belum menunjukkan tingkat kesejahteraan yang tinggi.(Rachmat, 2013)

Kumpulan metode dan teknik yang digunakan untuk mengubah bahan mentah menjadi makanan atau mengubah makanan menjadi bentuk lain untuk dikonsumsi oleh manusia atau oleh industri pengolahan makanan. Pengolahan makanan membutuhkan ladang bersih untuk memproduksi produk makanan menarik, dapat dipasarkan dan tahan lama.(Citra Kunia putri dan trisna insan Noor, 2013). Sesuai dengan namanya, Kawasan Balai Latihan Kerja Sorong menyediakan banyak tanaman salah satunya adalah labu kuning yang merupakan bahan yang mudah didapat karena banyak dibudidayakan oleh masyarakat dan bahan tersebut juga memiliki nilai gizi yang tinggi.(Pertiwi et al., 2020).Labu kuning membawa banyak manfaat dan nilai jual yang lumayan, hanya jika masyarakat atau pedagang dapat mengelolanya dengan baik. Fakta menunjukkan bahwa pengelolaan produksi labu kuning menjadi produk pangan belum dilakukan secara optimal.

Labu kuning saat ini hanya diolah sebagai pelengkap hidangan sayur. Pemanfaatan labu kuning menjadi produk yang lebih bernilai yaitu produk kue lumpur labu kuning, kue labu kuning, dan puding labu kuning.

Dengan demikian diharapkan dengan adanya pelatihan pengolahan hasil pertanian dapat memberikan manfaat pada masalah ekonomi.(Soekamto \& Fahrizal, 2019)Alasan kami melakukan penelitian adalah untuk mendorong pertanian menuju pertanian yang tangguh, berdaya saing, berkelanjutan dan berwawasan lingkungan, mewujudkan ketahanan pangan melalui peningkatan produksi komoditi pertanian dan penganekaragaman komsumsi pangan(Oktarina, n.d.)dan guna mempercepat upaya memberdayakan ekonomi petani, merupakan inti dari upaya pembangunan pertanian/pedesaan. Upaya tersebut dilakukan untuk mempersiapkan masyarakat pertanian menjadi mandiri dan mampu memperbaiki kehidupannya sendiri.(Purwanto, 2009).

Maka tujuan penelitian ini dimaksudkan1) Untuk mempelajari bagaimana cara memanfaatkan sumberdaya alam untuk dihasilkan menjadi bahan pangan2) mengolah bahan mentah menjadi berbagai macam produk hasil yang bermanfaat3)Untuk meningkatkan dampak perekonomian masyarakat.

\section{METODE PENELITIAN}

Penelitian ini bertempat di Balai Latihan Kerja Sorong yang merupakan tempat pelatihan bagi calon tenaga kerja yang siap pakai serta berkualitas. Metode yang digunakan dalam kegiatan 
ini dilakukan dengan beberapa pendekatan yaitu :1) Penyuluhan dilakukan untuk memberikan gambaran kepada masyarakat tentang besarnya pemanfaatan labu kuning menjadi aneka olahan makanan bagi masyarakat Sorong. 2) Pelatihan dilakukan untuk mengembangkan pengolahan labu kuning dengan menghasilkan berbagai jenis makanan dan dapat meningkatkan taraf hidup masyarakat. Selain itu akan diberikan pelatihan bagaimana system budidaya tanaman labu sebagai upaya menjaga keberlanjutan lahan.

\section{HASIL DAN PEMBAHASAN}

\section{Isi dan Hasil Pembahasan}

Labu kuning merupakan bahan dasar makanan yang tidak sedikit orang menggemarinya, selain rasanya yang enak, harganya juga terjangkau dan mudah ditemukan dimana saja. Dikota Sorong sendiri masih sedikitnya pengolahan yang berbahan dasar labu kuning, melihat hal ini kami melakukan penelitian tentang olahan apa saja yang dapat dibuat oleh labu kuning.

Dari hasil penelitian tersebut, labu kuning dapat menghasilkan berbagai olahan pangan yang enak dan menarik . Bahan dasar dari labu kuning tersebut dapat menghasilkan beberapa jenis makanan seperti:

- Kue labu kuning.

- Kue lumpur labu kuning.

- Puding labu kuning.

\section{Bahan yang dibutuhkan untuk pembuatan cake labu kuning}

$200 \mathrm{gr}$ menteg a
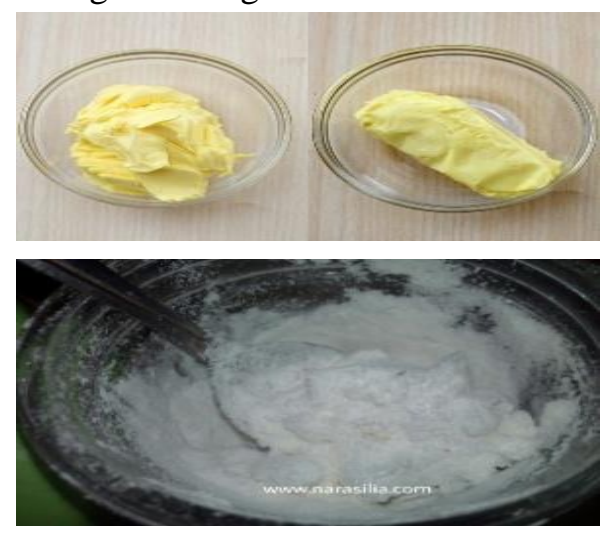

4 kuning telur
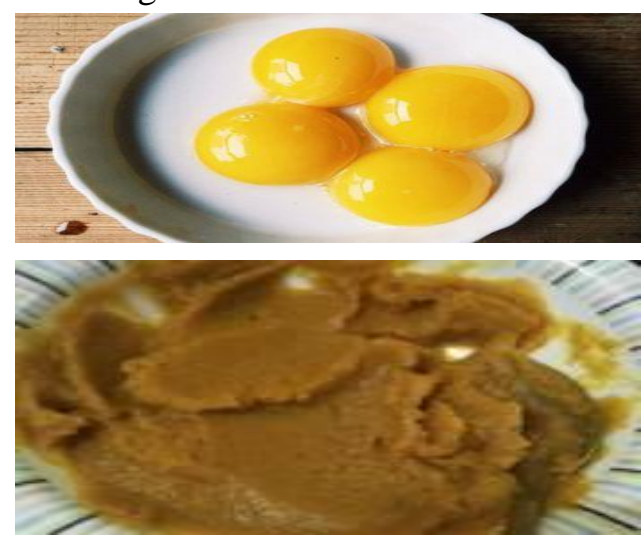

200gr labu kuning dihaluskan 
$250 \mathrm{gr}$ Tepung terigu ,

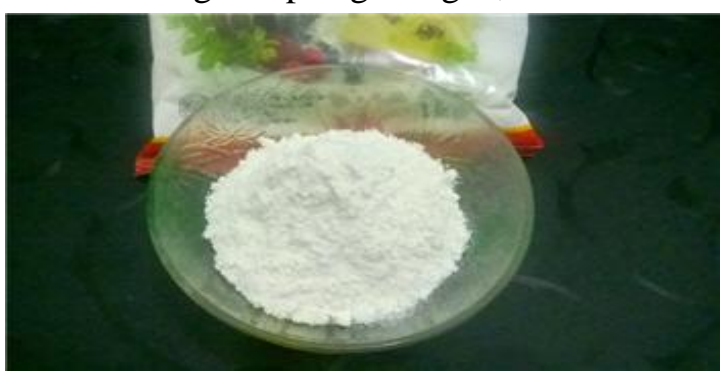

$1 / 2$ sdt.Baking powder

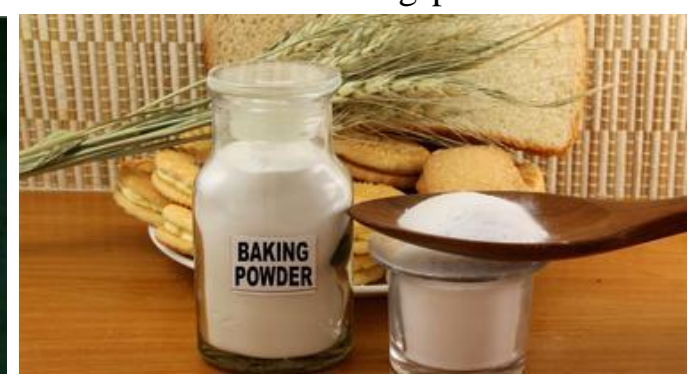

\section{Cara Membuat}

1. Kocok mentega bersama gula halus sampai putih, tambahkan kuning telur satu persatu dan telur utuh lalu di kocok sampai mengembang.

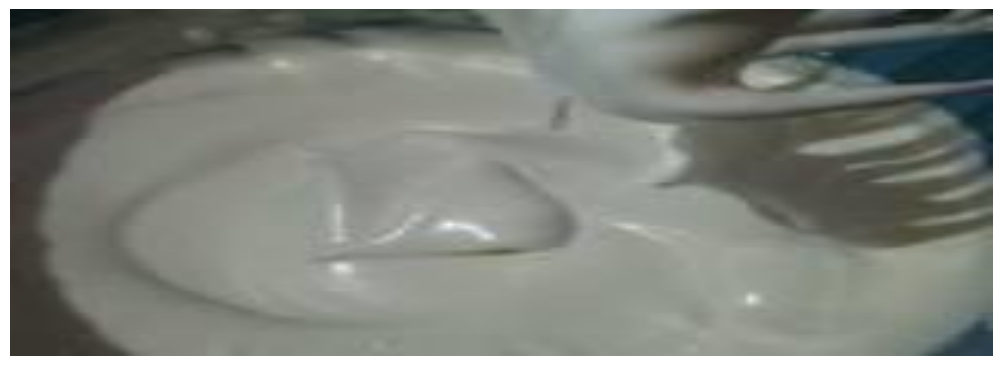

2. Ayak tepung terigu bersama baking powder jadi satu dan masukkan ke dalam adonan putih telur yang sudah di kocok tadi.

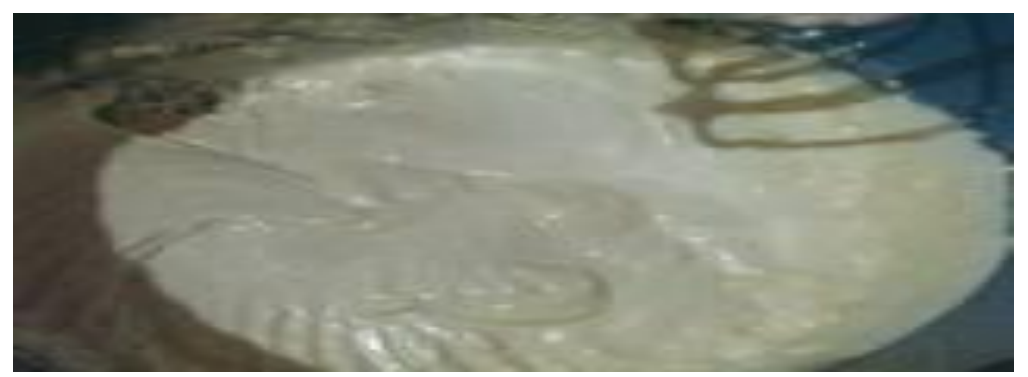

3. Masukkan adonan no.2 kedalam no.1 di aduk rata dengan memakai sendok kayu

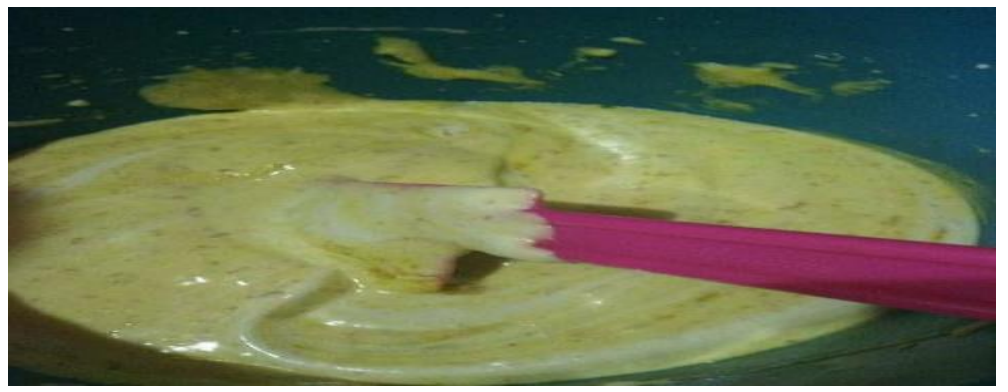


4. Setelah adonan kue tercampur rata, tuang adonan ke dalam loyang yang sudah di olesi mentega.

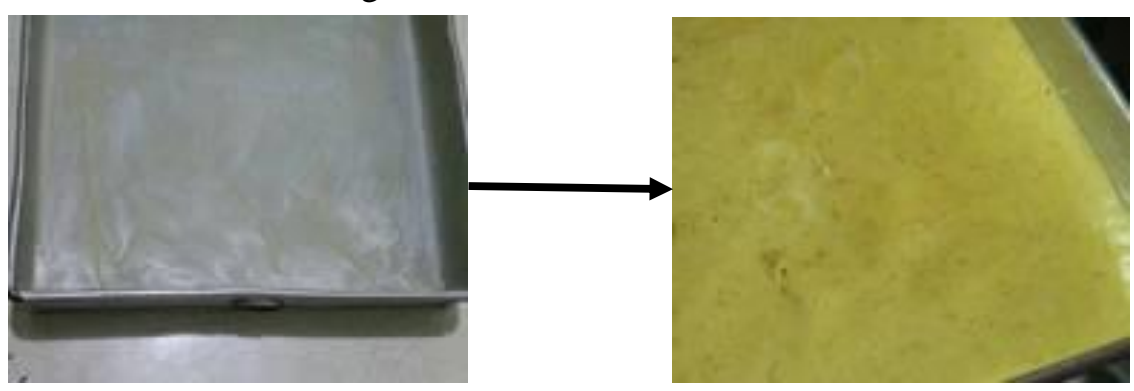

5. Masukkan ke dalam oven dan tunggu kurang lebih 45 menit.

6. Setelah kue matang, keluarkan kue labu dari oven dan diamkan dalam suhu ruangan hingga dingin dan dapat di potong.
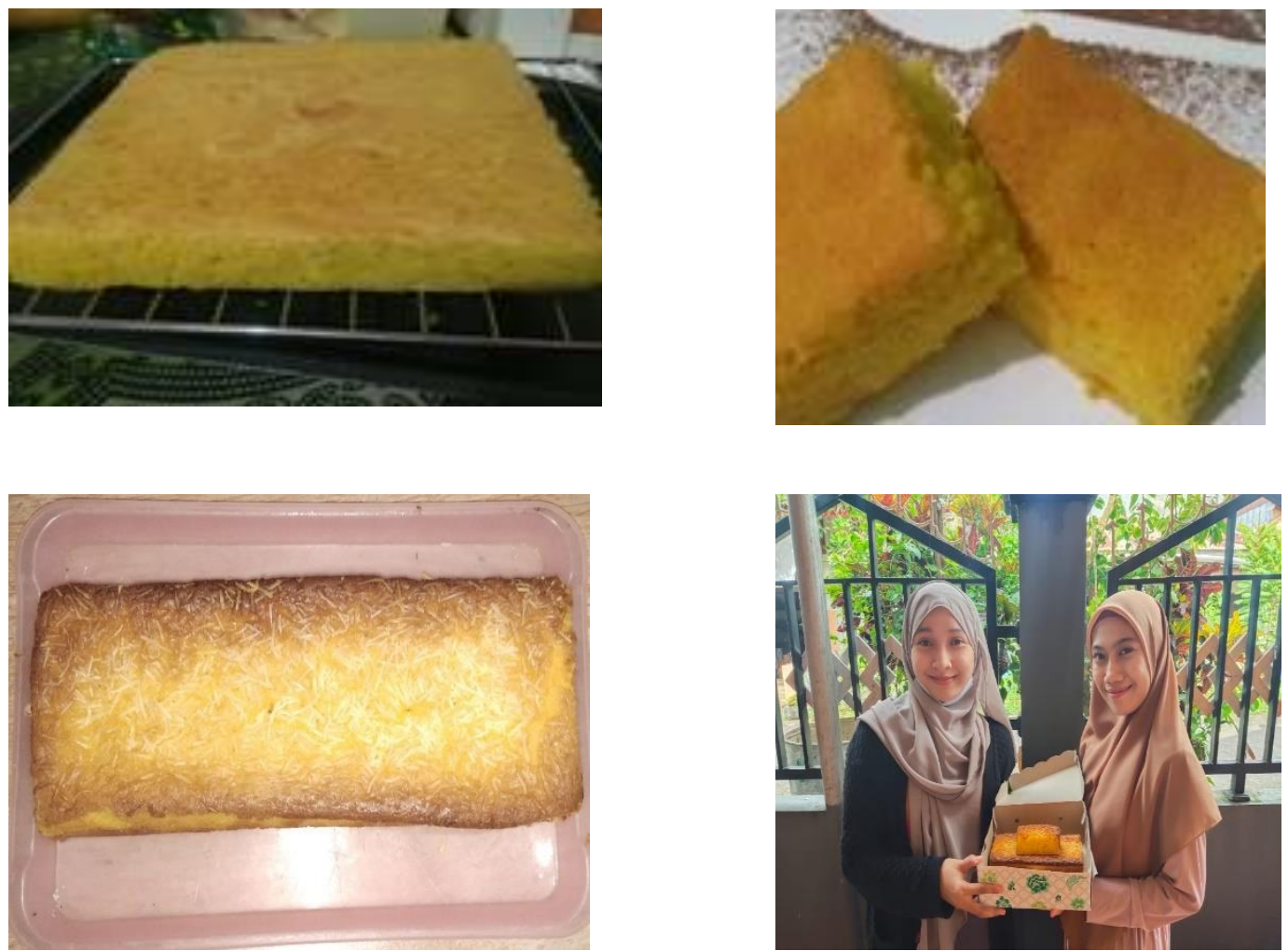

\section{SIMPULAN}

Penelitian ini bertujuan untuk mempelajari bagaimana cara memanfaatkan sumberdaya alam untuk dihasilkan menjadi bahan pangan, mengolah bahan mentah menjadi berbagai macam produk hasil yang bermanfaat dan untuk meningkatkan dampak perekonomian masyarakat, pada umumnya 
masyarakat selalu menginginkan sesuatu yang berbeda, tidak terkecuali dengan hal kuliner atau makanan.

Melalui kegiatan pelatihan pengolahan labu kuning, labu kuning dapat ditemui dimana saja setiap saat karena tidak tergantung pada musim, sehingga tidak perlu menunggu lama untuk dapat memproduksi dan mengkonsumsi..Oleh karena itu menciptakan berbagai makanan dari labu kuning, konsumen bisa lebih tertarik, seperti olahan labu kuning yang dapat di olah menjadi beberapa makanan,karena di kota sorong sendiri pengolahan labu kuning biasanya hanya sebagai sayuran.

Pemanfaatan labu kuning menjadi produk yang lebih bernilai yaitu produk kue lumpur labu kuning, kue labu kuning, dan puding labu kuning. Maka tujuan penelitian ini dimaksudkan untuk mempelajari bagaimana cara memanfaatkan sumberdaya alam untuk dihasilkan menjadi bahan pangan, mengolah bahan mentah menjadi berbagai macam produk hasil yang bermanfaat, untuk meningkatkan dampak perekonomian masyarakat..

\section{DAFTAR PUSTAKA}

Citra Kunia putri dan trisna insan Noor, 2011. (2013). 済無No Title No Title. Analisis Pendapatan Dan Tingkat Kesejahteraan Rumah Tangga Petani, 53(9), 1689-1699.

NurAini. (2004). PENGOLAHAN TEPUNG UBI JALAR DAN PRODUK-Oleh : Pps 702, $1-13$.

Oktarina, Y. 2005. (n.d.). Data Penelitian.pdf.

Pertiwi, R., Suhartatik, N., \& Mustofa, A. (2020). Ria Pertiwi, Nanik Suhartatik, Akhmad Mustofa *. 13(2), 104-110.

Purwanto, H. (2009). Teknologi Pengolah Hasil Pertanian. Mediagro, 5(1), 15-19.

Rachmat, M. (2013). Perspektif pengembangan industri pengolahan pangan di Indonesia. In Diversifikasi Pangan Dan Transformasi http://new.litbang.pertanian.go.id/buku/diversifikasi-pangan/BAB-III/BAB-III-8.pdf 
Soekamto, M. H., \& Fahrizal, A. (2019). Volume 1 Nomor (2) Halaman : 14-23 Volume 1 Nomor ( 2 ) Halaman : 14-23. 1, 14-23. 